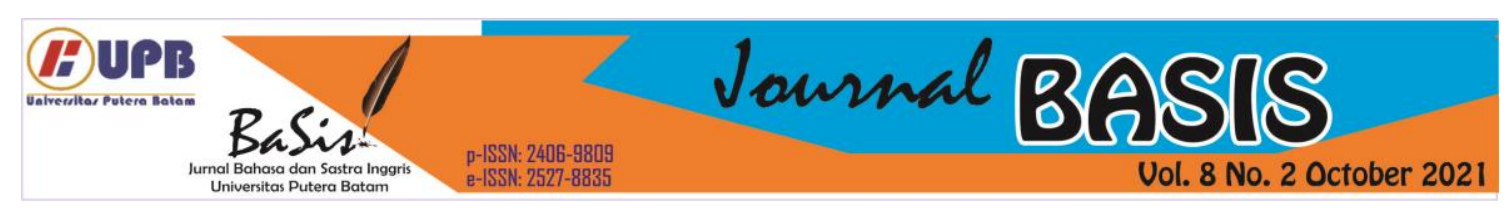

\title{
PSYCHOLOGICAL CONFLICT OF THE MAIN CHARACTER REFLECTED IN LADY BIRD MOVIE
}

\author{
Kicki Herdayanti ${ }^{1}$ \\ Universitas Putera Batam (UPB), Batam, Indonesia \\ Pb171210036@upbatam.ac.id \\ Robby Satria ${ }^{2}$ \\ Universitas Putera Batam (UPB), Batam, Indonesia \\ Robby@puterabatam.ac.id
}

\begin{abstract}
This research was useful for knowing the personality of the main character in the film. The researchers used the film Lady Bird as the object of research because this film was very interesting and told the story of a teenager who had very strong ambitions. This film was written by Greta Gerwig in 2017. The researcher used the psychoanalytic theory by Sigmund Freud. The study aimed to analyze the psychological conflict between ego, id and super ego trough the attitude and utterances of the main character. The method was qualitative descriptive. In result, researchers found 6 aspects of the id that are directly related to the main character, 2 aspects of the ego and 2 aspects of the superego. Therefore, the researcher concludes that in the main character in this film, she was more controlled by his id, where she was a form of personality that a person carried when she was born. The Id on Ladybird showed how she fulfilled a wish she deserved and felt that she enjoyed it more without realizing it.
\end{abstract}

Keywords: psychoanalysis, main character, Sigmund Freud

\section{INTRODUCTION}

Literary work is a form of appreciation created with high artistic value. According to (Wellek \& Warren, 1954) literary works are included in works formed from imagination. One of the literary works that is very interesting is film. Film is a visual medium which is now easily enjoyed by people. One of the interesting things to be analyzed in a film is a person's psychology. Psychology itself usually aims to determine the personalities of characters in both film and film. Usually the story script writer, makes a different character and psychology is shown ideally.
In a literary work, the character is an important role to build the story (McLaughlin, 1989). The character in a story have their own roles. There are several characters in a story, the main character, the protagonist, the supporting characters, the extras and the setting. The main character is a character who has a big part in a story, almost the whole story is filled by the main character (Sayuti, 2000). According to (Nurgiyantoro, 2007) characters in a story can be distinguished based on their role in a story, character appearance, and character. Therefore, the researcher will use the main character in a film to 
be analyzed. This study uses the 2017 film "Lady Bird" by Greta Gerwig.

The researcher uses psychoanalytic theory to examine the psychological aspects of the main character. The researcher used the psychoanalytic theory of Sigmund Freud. Freud was one of the psychologists who divided it into three aspects. He triggers a person's psychology as if it were an iceberg and consists of the id or conscious, namely as a desire when you want to achieve something desired, ego or preconscious, which is a balance that is usually present to fulfill the id. , and the last is the superego, which is a determinant such as good and bad decision making. These three psychological aspects will show their nature when they can work in balance.

Judging from Freud's theory of psychology, researchers are very interested in conducting research on the film "Lady Bird" by Greta Gerwig using Sigmund Freud's theory of psychoanalysis. Lady Bird movie was released in 2017 who has comedy drama genre, directed by Greta Gerwig. The film first premiered at the Telluride Film Festival on 01 September 2017 and was broadcast widely on 24 September 2017.

\section{REVIEW OF RELATED LITERATURES}

\subsection{Psychological}

Psychoanalysis was one of the theories originating from Sigmund Freud. He argued that psychoanalysis was a theory related to the subconscious and conscious human beings. (McLeod, 2019). He divided the aspect of psychologist into three level; id, ego and superego.

a. Id as aspect biologist

The id is a system that exists in us that has existed at birth. The id can be said to be the most basic personality system. The id can be seen from how we view something and the way we fulfill it. Therefore, the id can be said to be a conflict that exists within us because we have to satisfy ourselves by fulfilling the id. It is also biological aspect such as eating, sleeping, drinking, sex and others. The id usually occurs unconsciously and takes other things into account. The id already exists at birth so the id is an innate trait from birth. The id is the source for moving the ego and superego. The principle of the id is to fulfill his desires by fulfilling everything for satisfaction. The process carried out to fulfill the pleasure principle can be automatic such as when sneezing, blinking and others. Another processes such as when imagining food or the like (Koswara, 1991).

\section{b. Ego as aspect psychologist}

Ego is rationality. Ego is able to understand existing reality. $\mathrm{He}$ has a reality principle, so his work is based on existing realities. The ego has the role of weighing the id whether or not it should be done. He who later chooses whether to tend to the id or to the superego. The ego has the task of choosing the priority stimulus or instinct (determining which one is more important first) and determining when and how the stimulus is responded to with minimal risk (thinking about minimal risk). The ego fulfills the needs of the id from the reality principle as well as human morals. Unlike the id, the ego uses a secondary process that is used to think realistically to determine the success or failure of an action.

c. Superego as aspect sociologist

The superego enters into moral principles. The morals come from values that come from the environment. 
These moral values will later form conscience behavior or ideal ego. Conscience is like he punishes himself for violating existing morals. The ideal ego tends to be how ideal an individual is in a society. Superego including irrational because it will inhibit the id or satisfaction. An example of a superego that is considered irrational: when we have a family and have an accident such as bleeding, we end up calling an ambulance. On the way to the hospital, we definitely want to get there immediately before the bleeding gets worse and can't be helped, automatically there are many traffic signs that we have to violate, because if we don't do it, the bleeding will get worse. That is why the superego is not always rational but sometimes it is also irrational. He wants everything to be ideal, but if we clash with reality, sometimes the superego must be put aside because we have to choose our desires.

The researcher used some research as the inspiration for this research. The previous research were useful to complete this research. The first research which related to the psychoanalysis is Bulan et al., (2019)with title "The Psychological Analysis of Jamie Sullivan's Behaviors in Nicholas Sparks' Novel "A Walk to Remember". The aim of this study was to dig character Jamie with theory psychoanalysis. The researcher used documentation method to collect the data and qualitative descriptive method. This study presented informal and the result from this study, the researcher found that the main character was a good person who always wanted to help people who need some help. The character knew about morality then made the character were doing good attitude in the story.
Another research is from Qodariyah et al.,(2017) titled "The Major Characters in Gillian Flinn Novel "Sharp Object"; Psychoanalysis Freud". They made this study to get knowing the conflict psychological through the major character in novel. They used qualitative method then they collected the data by reading the novel. They used Freud's theory to analyze the novel. The final result, they got two conflict related to the main character.

There are the differences and similarities between previous research and this research. Both of the previous research used novel as the object of the research and the research used documentation method. The first research was to know about the personal character from the novel and the second was to get the conflict psychology from the novel. The similarities between this research and previous research was using the same theory of psychology by Sigmund Freud. Therefore the researcher used to analyze id, ego and superego from the main character through the Lady Bird movie (2017) by using the Freudian theory of psychoanalysis.

\section{METHOD OF RESEARCH}

The purpose study from this research was to tell the personality of the main character in the Lady Bird movie. This research used qualitative research method (Ratna, 2013). The research used to find out the three psychological conflict through the main character Lady Bird, namely the id, ego and superego proposed by Sigmund Freud. The researcher used some steps to collect the data: First, the researcher searched the movie and downloaded. Second, the researcher watched the movie many time to get better understanding. Then researcher make note to make it easier to analyze. 
After that the researcher found the data related to the theory, and the last, the researcher analyzed using the theory psychoanalysis.

After the data have collected, the researcher analyzed the data. The Research analyze by using theory Psychoanalysis by Sigmund Freud. This theory can describe the aspect of psychology in the movie "Lady Bird "through the main character. Psychological theory is a theory to explain the nature and development of personality. The priority elements in this theory are motivation, emotion and other internal aspects. The theory used to help determine the psychological aspects of personality experienced by characters mainly namely Christine McPherson which usually called "Lady Bird".

\section{RESULT AND DISCUSSION}

In this part, the researcher analyzed the data based on id, ego, and super ego in the movie Lady Bird (2017). Through this analysis, the researcher found some data that showed the dominant aspects of the main character.

\subsection{Id Conflict}

The aspect id in this movie can be found in the main character. The researcher was found the id aspect from the beginning of the story. The researcher found the aspect id of Lady Bird when her mother and she were in the car. She talked about the school she wanted. However, at that time, her mother did not allow her to go to school away from her mother and father. She really wants to go to school in another country. This can be seen in the following dialog:

Lady Bird: "I don't even want to go to school in this state anyway". "I hate California.
I want to go to the East Coast."

Mother: "your dad and I will barely be able to afford in state tuition."

Lady Bird: "there are loans and scholarship."

Mother: "Your father's company is laying people off right and left, did you know that? No of course not because you don't care about anyone but yourself" (Gerwig et al., 2017. 00:02:08 - 00:02:30)

The dialogue showed that id aspect of Lady Bird. By looking for the dialogue, she forced her will to continue her schooling abroad. She insisted on going to school in California while her family finances were not enough to fulfill her needs for studying abroad. She was looking for a way to not spend a lot of money on school by looking for scholarships. The id seen in this dialogue is Lady Bird's desire to study abroad and get what she wants. At that time, the id can be controlled by the ego and superego. Lady bird couldn't help but think about it for a while but it didn't last long.

Mother: "You should just go to City College, with your work ethic. City College and then to jail then back to City College. Maybe you'd learn how to pull yourself up and not expect everyone to do everything for you".

(They slow for a stop light and Lady Bird dramatically opens the door and rolls out of the car. Marion screams.) (Gerwig et al., 2017, p.6)

There are two factors that can affect human development, namely internal factors and external factors (Goh \& 
Arianto, 2019). In the lady bird character, she showed a more dominant internal factor because it came from within her. From the beginning story, she had showed her id then few minutes again she showed again by throw her body to the street. She did he bad act spontaneous without thinking first the cause and effect that she would got. She was slowly open the car door while her mom was driving the car. It was because her mom did not allow her to continue her study in other country. She did not want to hear any reasons from her mom. Although her mother had a strong reason behind her not letting her daughter go. Lady Bird just wanted what she wanted she can achieved. This problem is a form of id when she was dropping her body while the car is driving.

Julie: "I love this neighborhood."

Lady Bird: "Yeah, it's so beautiful."

Julie: "If I lived here I would definitely have my wedding in the backyard."

Lady Bird: "I'd have friends over all the time to study and eat snacks. I'd be like "Mom We're Taking The Snacks Upstairs To The Tv Room." Julie: "I'd have my own bathroom."

(Gerwig et al., 2017, p.8)

Lady Bird had a best friend in school, her name is Julie. She always did everything together with Julie. They was always going back together after school while shared stories. One time they came home from school together, they passed by a house that looked really nice, big and got them interested. She loved the house and wanted very much to own it. Then she imagined how if she had a nice and big house. Through this data it can be seen how she imagined and enjoyed it. Then the data is included in the category of id with she fulfills the pleasure she wants.

Lady Bird: (whispered to Julie) "If Danny and I get married and then his Grandma died, I'd inherit the Dream House."

Julie: "Wouldn't his parent's get it?"

Lady Bird: (realizing) "Oh yeah, we'd have to kill them. And kill his older brothers, too."(Gerwig et al., 2017, p.45)

One of the example of id is when someone referred to imagine something that will not necessarily happen is one form of the id. It happened by chance or crossed people's minds. From the dialogue Lady Bird and Julie, the main character Lady Bird told what she had been thinking to her friend. When Lady Bird and Julie were watching a band show at the cafe, it crossed her mind to kill Danny's grandmother after they got married. She will also kill Danny's brothers and he will take control of the house. At the beginning of the film, there was also a scene that showed that she really liked the house. Arianto, T \& Simanjuntak, D. (2020) in their article also mentions that justification for conflict of ideas can also occur due to the representation of someone who tries to fulfill the existence of the id. So when lady bird imagined something, it was her way of fulfilling the id. Another data show the id aspect is:

Jenna: "Wait, where do you live?" Lady Bird: "Oh, um, the 40s."

Jenna: "That's where our starter house was! Which street?"

Lady Bird: (lying, again) "Um, 44th it's, um, it's the three 
story blue house with the white shutters and the American flag in the front."

She describes the house that she and Julie lusted after last fall, Danny's Grandmother's house. (Gerwig et al., 2017, p. 48)

Lying is also how a person satisfies her id. She will be satisfied if her id is fulfilled. Although she will be worried if later her lie will be found out. In this film, Lady Bird just got to know Jenna, one of her friends who was popular and rich. She really wanted to be friends with Jenna because Jenna knew Kyle, the guy she met while watching a band. Kyle was Jenna's best friend. Then when in the parking lot, Jenna asked the address of his house. But he lied, she told Danny's grandmother's house address. She did not want Jenna to know that her house was not that nice and big. When the lady bird lies, it is a form of id that emerges from her. By lying she felt more relaxed and comfortable. Other data that shows the id aspect are:

(They laugh really hard. They catch their breath and notice that they are on the last slice of the block of cheese.)

Lady Bird: "We ate all the cheese!"

Julie: "its ok, Blocks of cheese vary in size that was a small one." Lady Bird: "So small." (Gerwig et al., 2017, p. 99)

The other data took when Lady Bird wanted to go to prom party with Kyle. In other hand, Kyle, Jenna and Jenna's boyfriend wanted to go to another event. She did not want to go, she just wanted to go to prom. Then when they on the way, Lady Bird asked Kyle to take her to her friend's house, Julie. When she arrived, she met
Julie and Julie cried due to something in her family. She comforted Julie, then they ate cheese to make them feel better. Eating is such an id aspect, because the id is an aspect biologist. So when Lady ate, it was her way of meeting her needs.

\subsection{Ego Conflict}

Everyone has their own ego, just like in this film. Lady Bird has an ego and wanted to get whatever she wanted and succeed. In this film there was a scene that showed how ego Lady Bird was in the film. Ego can be seen in the dialogue below.

Miguel and Shelly eat cereal. Larry reads the paper. Marion makes Lady Bird's

breakfast and her lunch.

Lady Bird: "Why can't I just make the eggs?"

Marion: "Because you take too long and make a big mess and then I have to clean

it up."

Shelly: (small voice) "Eggs aren't good for the environment, anyway." Lady Bird: (too loud) "WHAT?"

Miguel: "You heard her."

Marion (placing the eggs) "Here, eat quickly, PLEASE." (Gerwig et al., 2017, p. 14)

It happened when his family took breakfast at the dinner table. Her mother cooked eggs and prepared food for her lunch. He wants to cook himself. However, her mother didn't allow her to cook because it would take up a lot of time and make the kitchen a mess. Lady Bird felt a little annoyed. He wanted to cook his own eggs. But seeing his mother looking a little angry, he thought again to cook it himself. 
Lady Bird: "I don't want to have sex yet". "I haven't had sex yet, with another person."

Kyle: "No. Me neither." Lady Bird "Really?"

Kyle: "Yeah" Lady Bird: "cool" (Gerwig et al., 2017, p. 64)

When Lady Bird came to the Jenna's party at night, she was looking for Kyle. She saw that Kyle was reading a book and smoking beside the pool. Then she came to Kyle. They talked for a while and talked about hand rolled cigarettes and his family. Lady Bird sat down next to him. When Kyle touched her face, she felt nervous and excited. Then they was kissing. Then the dialogue above showed her ego. She was in her ego. She did not do more than kissed, she was still weighing what she was going to do. Ego here is interpreted as a counterweight to her id.

\subsection{Superego Conflict}

The superego sometimes overpowers everything. The superego makes people do things they should not do. Sometimes, the superego can make people commit crimes, cheat or act against existing norms. In this film, there was a scene of the main character doing something bad. The data that showed superego are:

Lady Bird: mom"

Mother: "we don't need to buy that."

Lady Bird: its only \$3. I am having a hard week."

Mother: "if you want to read it, we can go down to public library." Lady Bird: "I want to read it in bed."

Mother: "that something that rich people do. We are not rich people."
(Lady Bird walks away and then tucks the magazine underneath her sweater into the top of her skirt, sneakily stealing it.) (Gerwig et al., 2017, pp. 20-21)

The above data is a form of the superego that exists in Lady Bird. The data was taken when she was shopping at a supermarket with her mother. At that time, she wanted to buy a magazine. But the mother did not have enough money to buy it. Lady Bird wanted that magazine until she decided to steal it. She tucked the magazine into her skirt at the waist and covered it with a shirt. It is clear that what Lady Bird was doing is against the law and what Lady Bird was doing is included in the category of superego.

Ext. Teacher parking lot. Afternoon. Jenna and Lady Bird are decorating the nun mini-van with cans and streamers and attach a sign to the back that reads: "Just married to Jesus" (Gerwig et al., 2017, p. 58)

The statement above was showed that Lady Bird did something bad to her teacher. She and her friend decorated Sarah Joan's mini-van with cans, ribbons, and balloons and made a big paper with note "just married with Jesus". Her behavior was not very good to imitate, it was the same as having no morals. Sarah Joan was a nun at her school who always forbade to wear very short skirts. At the time, she was close to her friend, Jenna. Then she help Jenna to humiliate the nun.

\section{CONCLUSION}

There are some conclusions that can be drawn from the film Lady Bird through the main character. Lady bird had a strong will to get what she 
wanted. Based on Sigmund Freud's psychology theory, the id, ego, and super ego, Lady Bird dominates the id. The id is something that is in people born from birth, and in this film the character Lady Bird tried to fulfill the id in her way. However, it was undeniable that there were several egos and superegos against her. The way she tried to get her new school in another country was showed that she was an ambitious character even she had to leave her family and fight with his mother. The ego aspect from the character Lady Bird showed when she wanted to cook for herself but her mom avoided and she kept do that. The aspect of superego through the character is when she stole magazine in a store, which was breaking the norm. It was a bad attitude.

\section{REFERENCES}

Arianto, T \& Simanjuntak, D. (2020). Representation of ecocriticism in the folklore of Mak Ungkai spirit. Studies in English Language and Education, [S.1.], v. 7, n. 2, p. 576-591, sep. 2020. ISSN 24610275 . http://erepository.unsyiah.ac.id/SiELE/a rticle/view/16822

https://doi.org/10.24815/siele.v7i 2.16822.

Bulan, N. P., Ida Setianingsih, N. K. A., \& Winaya, I. M. (2019). The Psychological Analysis of Jamie Sullivan's Behaviors in Nicholas Sparks' Novel "A Walk to Remember." Humanis, 23(4), 271.

https://doi.org/10.24843/jh.2019. v23.i04.p03

Gerwig, G., Lee, B., \& McWilliams, J. (217). Lady Bird (p. 115). Universal Picture.

Goh, M., \& Arianto, T. (2019). An effect of psychological conflict to Elsa personality development in Frozen: psychological approach. Jurnal Basis, 6(2), 163.

https://doi.org/10.33884/basisup b.v6i2.1412

Koswara, E. (1991). Teori-teori Kepribadian: Psikoanalisis, Behaviorisme, Humanistik.

Eresco. McLaughlin, T. (1989). Literature the Power of Language. Harcourt Brace Jovanovich, Inc.

McLeod, D. S. (2019). Psychoanalysis. Simply Psychology. https://www.simplypsychology.o $\mathrm{rg} / \mathrm{psychoanalysis.html}$

Nurgiyantoro, B. (2007). Teori Pengkajian Fiksi. Gadjah Mada.

Qodariyah, B., Rohmah, A., \& Sugiyani, N. (2017). The Major Characters in Gillian Flynn Novel "Sharp Objects" (A Psychoanalysis Freud). Channing: Journal of English Language Education and Literature, 2(2), 78-85. https://doi.org/10.30599/channin g.v2i2.268

Ratna, N. K. (2013). Teori, Penelitian, dan Teknik Penelitian Sastra. Pustaka Belajar. Sayuti, A. S. (2000). Berkenalan dengan Prosa Fiksi. Gama Media.

Wellek, R., \& Warren, A. (1954). Theory of literature. Jonathan Cape Thirty Bedford Square London. 